\title{
A Cross-Culture Study of Academic Procrastination and Using Effective Time Management
}

\author{
Martina Košíková1, Veronika Loumová2 ${ }^{*}$, Jana Koval'ová3, Petra Vašaničová1, \\ Viktoria Mykhaylivna Bondarenko ${ }^{4}$
}

\author{
1 Department of Mathematical Methods and Managerial Informatics, Faculty of Management, University of Prešov, \\ Konštantínova 16, 08001 Prešov, Slovakia \\ 2 Department of Management, Faculty of Management, University of Prešov, Konštantínova 16, 08001 Prešov, Slovakia \\ ${ }^{3}$ Department of Managerial Psychology, Faculty of Management, University of Prešov, Konštantínova 16, 08001 Prešov, Slovakia \\ ${ }^{4}$ Department of Business-administration, Faculty of History and International Relations, Uzhhorod National University, \\ Narodna Square 3, 88000 Uzhhorod, Ukraine \\ * Corresponding author, e-mail: veronika.timkova@smail.unipo.sk
}

Received: 24 October 2018, Accepted: 23 May 2019, Published online: 29 November 2019

\begin{abstract}
Duties, tasks, different situations or decisions need to be resolved on a daily basis. However, it often happens that because of overinformation from different sides, an excessive number of tasks, the fast pace of life, and so on we tend to procrastinate important tasks for later. This phenomenon can occur in almost every area, including the academic area. This contribution, therefore, addresses the occurrence of academic procrastination and the establishment and use of time management by university students. The main objective is to identify possible differences in procrastination and the right use of time management in a cross-cultural context. A research sample consisted of 292 students from the Uzhhorod National University and from the University of Prešov, on which we surveyed the rate of procrastination and rate of time management through our own questionnaire. Subsequent testing of the obtained data revealed that there are statistically significant differences in procrastination between Ukrainian and Slovak students, but differences in time management have not been confirmed.
\end{abstract}

\section{Keywords}

procrastination, academic procrastination, time management, cross-culture, students

\section{Introduction}

Present time can be characterized as a hasty and fast period in which there are constantly rapid changes. If one wants to be able to cope with this "time stress", it is important to know how to effectively handle personal time (Košíková et al., 2017). Every person manages and organizes his own time based on his own deliberation (Sojka et al., 2010). If we tend to waste our precious time on irrelevant things or postpone important tasks for a later, we can talk about procrastination. There are different types of procrastination, and this paper focuses on academic procrastination that is related to students.

\section{Theoretical basic}

Procrastination may be specified as a postponement of duties or activities for a later time, even if an individual is trying to accomplish equally valuable performance and to successfully complete the activity till the end (Steela, 2007). Procrastination occurs in various areas, whether work, private or academic. The issue of procrastination in management was studied by Birknerová et al. (2015). The aim of their research was to find out the links between aspects of motivation to performance, time planning, and procrastination. Their research sample consisted of 111 respondents, with an average age of 32.80 years, which were from the administrative, finance, business or education working area. That research was based on a hypothesis that identified statistically significant links between aspects of motivation to performance and aspects of procrastination as well as aspects of motivation to exercise and time planning. Three different questionnaires were used for that research: MPQ (Motivation to Performance Questionnaire), PRQ (Procrastination Questionnaire), 
TPQ (Time Planning Questionnaire). The results showed a close link between time planning and the associated procrastination of employee performance. It turned out that those respondents who think that it is most important to organize their tasks in advance and not to postpone duties at a later stage while also putting high requirements on their work. On the other hand, in the case of poor-quality and late preparation, they feel anxiety from the lack of time, which has a negative impact on performance at work.

However, the present paper focuses on investigating the incidence of academic procrastination. Researches prove that procrastination in the academic area is nothing special. As is stated in Schraw et al. (2007), more than $50 \%$ of university students procrastinate regularly and circa 20-40\% students procrastinate occasionally. According to Schouwenburg et al. (2004), only $20 \%$ of students postpone their duties occasionally and more than $70 \%$ of students often procrastinate.

Research on procrastination was carried out in Slovakia by the authors Nábělková and Ledajová (2012), who examined the possible negative relationship between: a) procrastination and self-esteem, b) internalistic orientation of personality and volitional regulation. They wanted to support the assumption that these factors could be considered protective in relation to procrastination. The research was conducted through a set of 5 questionnaires on 216 university students, with an average age of 22.3 years. The gender distribution was in the proportion of $57 \%$ of women and $43 \%$ of men. The findings highlighted the negative relationship of volitional regulation with general procrastination and a moderately negative relationship with academic procrastination. General procrastination correlates negatively with self-esteem. Research has failed to support the supposed relationship between procrastination and the internalistic orientation of the personality.

In 2009, Özer et al. (2009) explored the reasons and prevalence for academic procrastination, focusing on gender differences in the causes of student procrastination. The first study was applied to 203 Turkish university students and the validity and reliability of the scale were tested by factor analysis, which was subsequently revised. The second study was participated by 784 students, of which there were 363 women and 421 men, with an average age of 20.6 years, and standard deviation of age equal to 1.74 years. The results showed that $52 \%$ of students reported frequent postponement of academic duties, while men procrastinate more often than women. Significantly more women than men stated their postponement of duties later on was because of fear of failure and laziness. On the other hand, men stated that the reason is because of risking and revolting against control, and rebellion.

Procrastination is often associated with a feeling of discomfort. Research realized by Hen and Goroshit (2018) examined the consequences of procrastination on students, their feeling of discomfort in connection with procrastination, and the desire to change this habit. They assumed that there is a relationship between decision-making procrastination, academic procrastination, and student feelings (feeling of discomfort, the desire to change this habit). 375 college students of social sciences from northern Israel participated in this study. The results of this research doubt the traditional experience that procrastination is mostly associated with feelings of discomfort. This study suggests that while decision-making procrastinators experience the inconvenience of postponing the decision, academic procrastinators want to change these habits but do not report feelings of discomfort. The findings also indicate the difference between these two types of procrastination. For some students, postponing duties can serve as an immediate emotional relief, followed by negative academic results that increase the desire to change this habit.

Procrastination has been studied as a dysfunctional, self-effacing behavior that ultimately results in undesirable outcomes. However, Choi and Moran (2009) found a different form of procrastination (i.e. active procrastination) that leads to desirable outcomes. It follows that occasional procrastination can also have a positive impact on the personality of a person; it can be beneficial when the person knows how to handle it reasonably. On the other hand, we encounter its most extreme form - chronic, which is manifested by discomfort, nervousness, increased anxiety, irritability, mood swings, despair, and demotivation. Such feelings affect not only overall performance and learning but also health impairment or tense social relationships (Pychyl, 2009). To solve this problem, it is first and foremost important to recognize and identify it. By accurately determining the causes of procrastination, it is possible to eliminate its occurrence. One of the possible solutions to procrastination is the consistent planning of a person's time and the use of so-called time management.

Any company wants to achieve prosperity and its goals for both its owners as well as its employees but also for the company itself (Gallo et al., 2018). Effective managing business performance is a relatively complex and difficult process, which is undergoing significant changes both in practice and in research. It seems that the traditional 
business performance management based primarily on financial management has reached its limits and in recent years we have seen the development of new non-traditional indicators, methods and models based primarily on nonfinancial methods, in particular on strategic and other qualitative indicators (Rajnoha et al., 2016). In the current dynamic environment, it is therefore essential that each company uses its time as effectively as possible. Time management means first and foremost the best use of time when it comes to efficient division and planning of individual activities (Stanková, 2016). Time management is the process of planning and performance of awareness of control over time spent on specific activities, particularly in order to increase efficiency and productivity (Singh and Jain, 2013). As is stated in Sojka et al. (2010), the sense of time management is to control own time and work. Time management is one of the most important issues in modern business; time is one of the main sources of success in any area (Singh and Jain, 2013). Particularly important is the academic sphere, while it is very important for students to monitor and detect the extent of their ability to manage their time. University students must be able to effectively manage their time and be able to classify their tasks properly, especially because it is a diverse combination of tasks, each of which requires different preparation times. These are tasks such as different projects, seminar assignments, credits, examinations, etc. Lahmers and Zulauf (2000) argue that the amount of time spent studying in part reflects how effectively students manage the many activities in their lives, whether it be academic pursuits, curricular involvement, recreation, socializing with friends, or the necessary activities of life, such as personal hygiene, eating, and sleeping.

The area of time management is the center of attention in much of existing researches which are mostly oriented on the use of time management, especially in working life (Azar, 2017; Burt et al., 2010; Singh and Jain, 2013). Academic time management was examined by Tsai and Liu (2015), who studied the relationship between time management skills and Facebook interpersonal skills in terms of the academic success of university students. The study results have shown especially the negative aspects of the use of Facebook in connection with academic success. The results have pointed out that students who talk less to friends on Facebook have better results in their academic performance because of their effective time management skills. The present paper, inter alia, focuses to identify the occurrence of time management of students.

\section{Data and methodology}

The main objective of the paper is to identify the differences in the occurrence of academic procrastination and the use of effective time management in the cross-culture context of Slovak and Ukrainian students. For this contribution, the following research hypotheses were established:

- H1: We assume that there are statistically significant differences in the occurrence of academic procrastination between Slovak and Ukrainian students, i.e. with respect to the nationality of the respondent.

- H2: We assume that there are statistically significant differences in the using effective time management between Slovak and Ukrainian students.

The data needed for the analysis were obtained through the questionnaire of the authors, which was the primary source of the data. The research sample consists of 292 respondents $(\mathrm{N}=292)$, while the portfolio of the research sample consisted of students of the Uzhhorod National University (32.5\%) and students of University of Prešov from the Faculty of Management (67.5\%). The questionnaire consisted of two basic parts. The first part contained closed-ended categorization questions needed to classify respondents by age, gender, residence, and nationality. The second part was focused on detecting the occurrence of procrastination and the efficient use of time management. The majority of individual items were evaluated by respondents on a 5-point Likert scale, which expresses the degree of consent ( 1 = strongly disagree/ no/ never/ inconsequent, 5 = strongly agree/ yes/ always/ consistent). The questionnaire also contained open-ended questions identifying the reasons and causes of the procrastination, as well as the timetable of the students.

The Statistica statistical software was used to process the research results. Individual variables were subjected to the tests of data normality (Doornik-Hansen test, Shapiro-Wilkov test, Lilliefors test a Jarque-Ber test), which showed that none of the variables had a normal distribution. In order to assess the significance of differences in the occurrence of procrastination and the efficient use of time management, we used the Mann-Whitney U test, which is suitable for analyzing the data available to us and does not require a normal distribution.

Mann-Whitney $U$ test is a non-parametric test based on the comparison of medians of two independent samples. The test assumes the same deviations in two populations, from which two samples are compared, i.e. it tests whether the difference in the average of an order of the two groups 
is statistically significant or just random (Martínez-Murcia et al., 2012; Rimarčík, 2007).

Calculation of $U$ value is achieved by the following expression Eq. (1) (Martínez-Murcia et al., 2012) while from equation we obtain two different values $\left(U_{1}\right.$ and $\left.U_{2}\right)$

$U_{1(2)}=R_{1(2)}-\frac{n_{1(2)}\left(n_{1(2)}+1\right)}{2}$

where $n_{1(2)}$ is the sample size form maple set 1(2), $R_{1(2)}$ is the sum of the ranks in sample set 1(2).

The smaller value of $U_{1}$ and $U_{2}(U)$ is the one used when consulting significance tables. The sum of the two values is given by Eq. (2)

$U_{1}+U_{2}=R_{1(2)}-\frac{n_{1}\left(n_{1}+1\right)}{2}+R_{2}-\frac{n_{2}\left(n_{2}+1\right)}{2}$.

By taking into account that $R_{1}+R_{2}=\frac{N(N+1)}{2}$ and

$N=n_{1}+n_{2}$, we find that the sum is given by Eq. (3)

$U_{1}+U_{2}=n_{1} n_{2}$

We reject the null hypothesis that the two samples come from identical populations and accept the alternative hypothesis that the two populations have unequal means, if $U \leq U_{\alpha}^{\prime}$ (Freund et al., 1988).

\section{Results and discussion}

Table 1 shows the results of testing the first hypothesis which examines the existence of academic procrastination differences between Slovak and Ukrainian students.

Based on the Mann-Whitney $U$ test, we found that there are statistically significant differences in the occurrence of academic procrastination between Slovak and Ukrainian students. Therefore, the hypothesis H1 has been confirmed. According to research results, procrastination of Slovak students (the mean response was 3.3 with a standard deviation of 0.8754 ) occurs more often than of Ukrainian students (the mean score was 3.7 with a standard deviation of 0.6781). Based on the students' answers, the most frequent reasons for postponement of work and duties include lack of time reserved for the given task, which is related to ineffective time management, laziness, and reluctance to deal with the given task or the difficulty of the task.

The results of the Mann-Whitney $U$ test are visually complemented by Fig. 1, which displays a categorized histogram of the distribution of the incidence of procrastination in Slovak and Ukrainian students. The y-axis is the number of observations in a given group, the $\mathrm{x}$-axis presents the country of origin of the student and the frequency of occurrence of procrastination among students from that country. Value 1 means that students will postpone their duties always, 2 often, 3 - on average, 4 - sometimes and 5 - never.

As a consequence of the incidence of academic procrastination, we also examined the consistency of the fulfilling students' duties and the existence of differences in the cross-cultural context. The existence of statistically significant differences confirms the test results in Table 2. The test results in Table 2 confirm the existence of statistically significant differences. Surprisingly, results show that despite the fact that the occurrence of academic procrastination is more frequent among Slovak students, they are more conscientious when fulfilling their duties than Ukrainian students. The mean response score for Slovak students was 3.5 with a standard deviation of 0.689 , while Fig. 2 is showing that the most frequent answers were primarily average and consistent fulfillment of duties. The

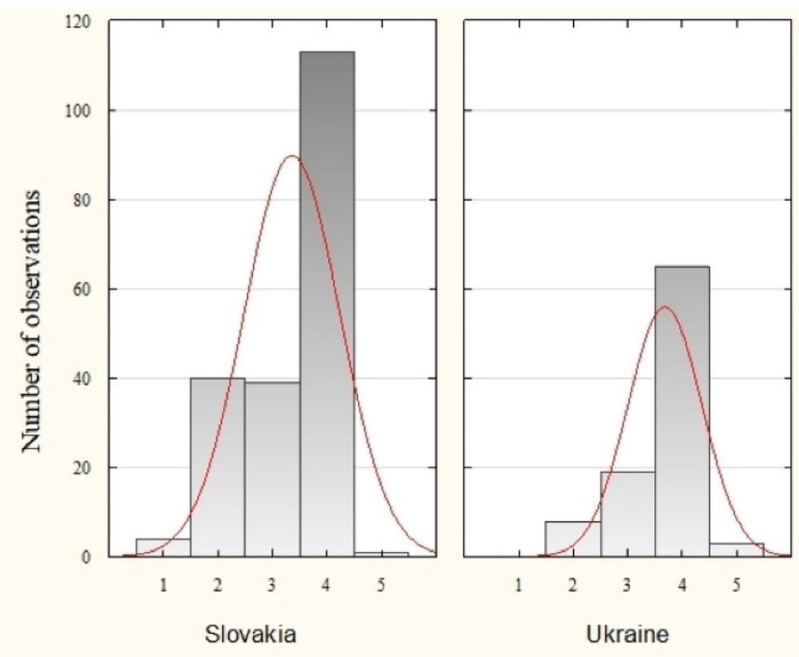

Fig. 1 Categorized histogram of the occurrence of academic procrastination

Table 1 Results of Mann-Whitney U test - Academic procrastination

\begin{tabular}{|c|c|c|c|c|c|c|c|}
\hline \multirow{2}{*}{$\begin{array}{l}\text { Dependent: } \\
\text { Academic } \\
\text { procrastination }\end{array}$} & \multicolumn{7}{|c|}{ Independent variable: Country of origin. Marked tests are significant at $p<0.050$} \\
\hline & Valid $N$ & Rank Sum Group & $U$ & $Z$ & $p$-value & Z Adj. & $p$-value \\
\hline Slovakia & 197 & 27162.5 & \multirow{2}{*}{7659.5} & \multirow{2}{*}{-2.51} & \multirow{2}{*}{0.012} & \multirow{2}{*}{-2.88} & \multirow{2}{*}{0.004} \\
\hline Ukraine & 95 & 15615.5 & & & & & \\
\hline
\end{tabular}


Table 2 Results of Mann-Whitney U test - The consistency of duties fulfillment

\begin{tabular}{lccccccc}
\hline \multirow{2}{*}{$\begin{array}{l}\text { Dependent: } \\
\text { Consistency }\end{array}$} & \multicolumn{5}{c}{ Independent variable: Country of origin. Marked tests are significant at $\mathrm{p}<0.050$} \\
\cline { 2 - 8 } & Valid N & Rank Sum Group & $\mathrm{U}$ & $\mathrm{Z}$ & $\mathrm{p}$-value & Z Adj. & $\mathrm{p}$-value \\
\hline Slovakia & 197 & 31184.0 & 7034.0 & 3.44 & 0.001 & 3.82 & 0.0001 \\
Ukraine & 95 & 11594.0 & & & & & \\
\hline
\end{tabular}

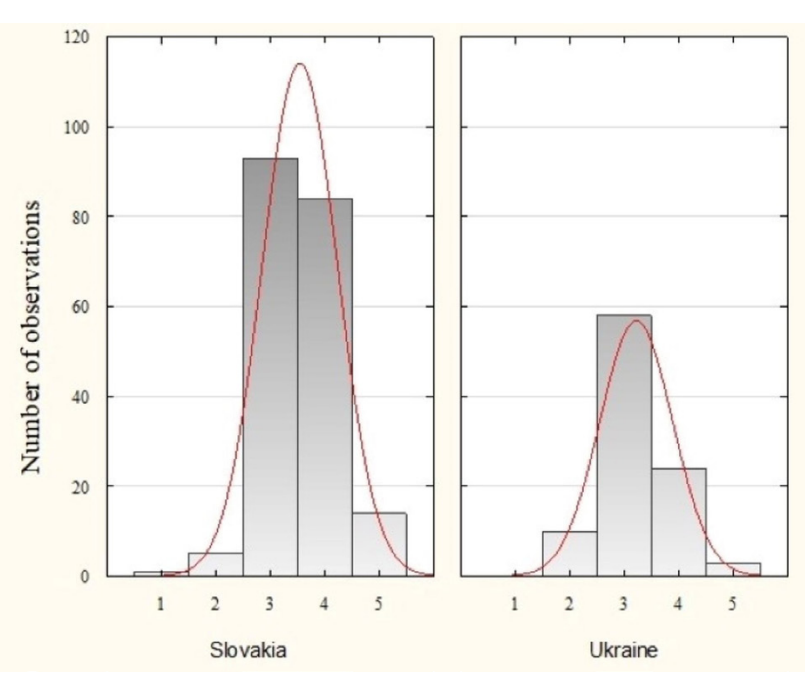

Fig. 2 Categorized histogram of the occurrence of consistency of duties fulfillment

average score of Ukrainian students was 3.2105 (standard deviation 0.6668 ), which also corresponds to the most frequent answers, namely the average fulfillment of duties.

The second research hypothesis $\mathrm{H} 2$ focuses on differences in effective time management. Respondents answered the questions whether they have time management in place, how effective their time management is, whether they are accomplishing their tasks on time and whether their time management allows them to "save" their free time. Delegating tasks, sorting tasks according to difficulty, concentrating on duties and eliminating time thieves were also examined. By using the Mann-Whitney $U$ Test we revealed that there are no statistically significant differences between the Slovak and Ukrainian students in the efficient use of time management. The test results of the second hypothesis are shown in Table 3 in detail. We did not confirm the hypothesis $\mathrm{H} 2$.

We, therefore, tested whether there exist at least statistical significant differences in individual time management components between Slovak and Ukrainian students. The items of the questionnaire, in which statistically significant differences were recorded, are shown in Table 4.

Statistically significant differences in the individual time management components were recorded in items 15,17 and 18 (time-saving, delegating tasks, and ability to concentrate on tasks). In item no. 15 "Does your time planning save time for your task fulfillment?" Higher scores were made by Ukrainian students whose average answers were 3.85, so they were closer to the answer "rather yes" unlike the Slovak 3.59. Fig. 3 shows how the student's responses were represented. While in the case of Slovak students prevailed answers were "rather yes" and "do not know", for Ukrainian students it was predominantly "yes" and "rather yes".

Table 3 Results of Mann-Whitney U test - Time management

\begin{tabular}{|c|c|c|c|c|c|c|c|}
\hline \multirow{2}{*}{$\begin{array}{l}\text { Dependent: } \\
\text { Time management }\end{array}$} & \multicolumn{7}{|c|}{ Independent variable: Country of origin. Marked tests are significant at $\mathrm{p}<0.050$} \\
\hline & Valid N & Rank Sum Group & $\mathrm{U}$ & Z & p-value & Z Adj. & p-value \\
\hline Slovakia & 197 & 28595.0 & \multirow{2}{*}{9092.0} & \multirow{2}{*}{-0.39} & \multirow{2}{*}{0.695} & \multirow{2}{*}{-0.39} & \multirow{2}{*}{0.693} \\
\hline Ukraine & 95 & 14183.0 & & & & & \\
\hline \multicolumn{8}{|c|}{ Table 4 Differences in time management components } \\
\hline $\begin{array}{l}\text { Items of the } \\
\text { questionnaire }\end{array}$ & Country & Mean & Standard & lation & U test & Z & $\mathrm{p}$-value \\
\hline \multirow{2}{*}{ Item no. 15} & Slovakia & 3.59 & 1.0 & & \multirow{2}{*}{7815.5} & \multirow{2}{*}{-2.280} & \multirow{2}{*}{0.023} \\
\hline & Ukraine & 3.85 & 1.1 & & & & \\
\hline \multirow{2}{*}{ Item no. 17} & Slovakia & 2.05 & 0.8 & & \multirow{2}{*}{7441.0} & \multirow{2}{*}{2.834} & \multirow{2}{*}{0.005} \\
\hline & Ukraine & 1.80 & 0.9 & & & & \\
\hline \multirow{2}{*}{ Item no. 18} & Slovakia & 4.21 & 0.8 & & \multirow{2}{*}{7854.0} & \multirow{2}{*}{-2.223} & \multirow{2}{*}{0.026} \\
\hline & Ukraine & 4.44 & 0.7 & & & & \\
\hline
\end{tabular}

Note: Item no. 15. Do your time planning save the time of your task fulfillment? Item no. 17. Do you delegate tasks to someone else? Item no. 18. Can you concentrate on fulfilling the task? 

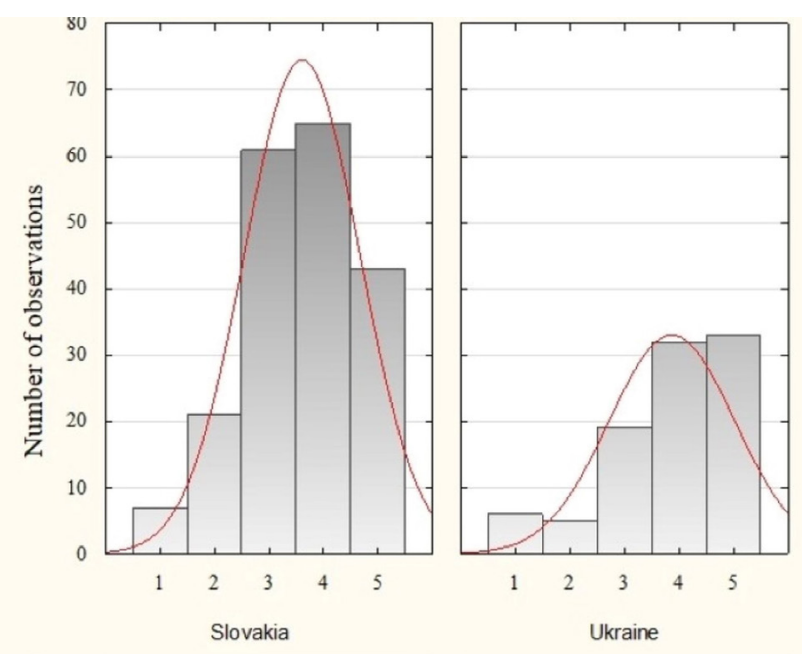

Fig. 3 Categorized histogram of the distribution of time-saving using planning

Significant differences were also found in item no. 17 "Do you delegate tasks to someone else?". In this case, Slovak students scored higher (2.05), who delegated their tasks somewhat more than Ukrainian students (1.80). On this issue, it was especially interesting that both Slovak and Ukrainian students delegated their responsibilities to others very little, or not at all because the predominant answers to the question were "no" and "rather not". Poor use of delegation of tasks can also be given by the nature of the tasks and duties that students have to fulfill. In most cases, these tasks are primarily intended to be performed by the individual, and it is undesirable for someone else to fulfill these tasks. The exact representation of respondents' answers to question no. 17 is shown in Fig. 4.

The last component of time management, which showed differences between Slovak and Ukrainian students, was item no. 18, which identified the ability to concentrate on assigned tasks. Again, Ukrainian students scored higher (average values of 4.44), and according to the questionnaire survey, they have no problem concentrating on the given tasks. The average score of Slovak students was somewhat lower at 4.21 points. This finding is also supported by the results in the previous section. It is possible to assume that less frequent postponement of Ukrainian students ("only sometimes") leads to a better possibility to focus on tasks (they answered from "rather yes" to "yes") and leads to a better time saving by establishing time management (in particular, they have tended to answer "rather yes").The distribution of students' answers to the question of concentrating on given tasks is shown in Fig. 5.
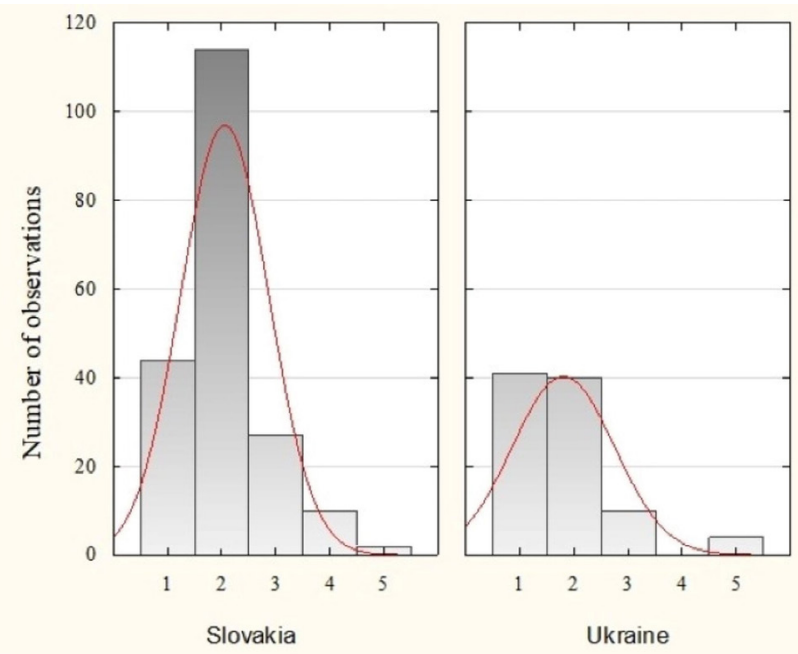

Fig. 4 Categorized histogram of distribution of delegating tasks
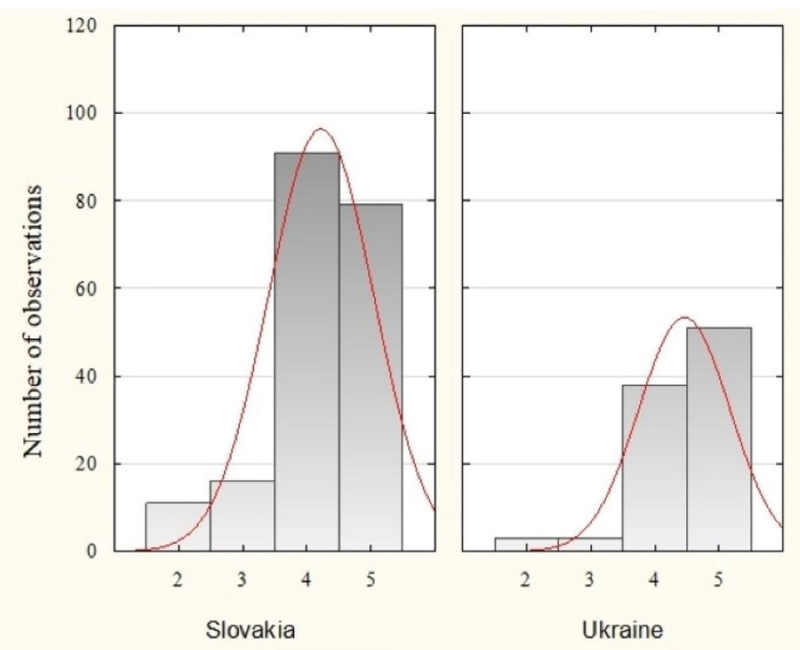

Fig. 5 Categorized histogram of the distribution of concentrating on tasks

\section{Conclusions}

The current highly competitive environment and the rapid pace of life often require a person to carefully plan his tasks and make efficient use of his time. The area of time management is very important both in working life, but also in personal or school (academic) life. The hasty period has forced people many times to unwillingly postpone their tasks for later, and to avoid some difficult tasks, even if the individual is trying to fulfill these tasks on time. It is then possible to talk about procrastination, which occurs frequently in different people, that it occurs in various areas, whether in management or in education. Procrastination can have a very negative impact and can cause serious problems, but it also has its positive side. The present paper focused on the study of procrastination and time management in the academic area, focusing on 
examining the occurrence of academic procrastination and the use of time management by university students.

The study aimed to identify the differences in the occurrence of academic procrastination and the use of time management in the cross-cultural context of Slovak and Ukrainian students. The research was carried out using a questionnaire method and results were processed using mathematical and statistical methods in the Statistica software. The research sample consisted of 292 students from the Uzhhorod National University and from the University of Prešov. Statistically significant differences between Ukrainian and Slovak students were confirmed in the occurrence of procrastination. In the case of time management, statistically significant differences in cross-cultural contexts have not been confirmed. The differences were significant only for some components of time management, namely when saving time by task planning, delegating tasks, and concentrating on work tasks.

Based on the research conducted, it has been found that the occurrence of procrastination and insufficient use of time management is a problem for both Slovak and Ukrainian students (frequent occurrence of procrastination, an insufficient delegation of tasks, insufficient time management). From the conducted survey, we can argue that a greater degree of consistency in the fulfillment of tasks occurs among Ukrainian students. It has been shown that Ukrainian students, who delegate their tasks less than Slovak, have a better ability to concentrate on tasks and then to save time in fulfilling these tasks if they plan it in advance. The occurrence of procrastination among Ukrainian students is also lower than among Slovak students. However, it is interesting that the consistency of the

\section{References}

Azar, S. (2017) "Time Management Behaviors Sanction Adoption of Flexible Work Arrangements", Journal of Economic Development, Management, IT, Finance, and Marketing, 9(1), pp. 12-24.

Birknerová, Z., Birkner, M., Šebeš, P. (2015) "Súvislost' medzi výkonovou motiváciou, plánovaním času a prokrastináciou v pracovnom procese" (Relationship between performance motivation, time planning and procrastination in the workflow), In: Možnosti merania prínosu l’udských zdrojov k výkonnosti organizácie, Bookman, Prešov, Slovakia, pp. 140-146. (in Slovak)

Burt, C. D. B., Weststrate, A., Brown, C., Champion, F. (2010) "Development of the time management environment (TiME) scale", Journal of Managerial Psychology, 25(6), pp. 649-668. https://doi.org/10.1108/02683941011056978

Choi, J. N., Moran, S. V. (2009) "Why Not Procrastinate? Development and Validation of a New Active Procrastination Scale", The Journal of Social Psychology, 149(2), pp. 195-212.

https://doi.org/10.3200/SOCP.149.2.195-212 tasks is, in contrast to the other results, higher for Slovak students. We assume that the differences in these areas can also be caused by the different functioning of the higher education system in Slovakia and Ukraine. This finding may also be due to the different mentality of students, education, or their social and economic situation in the country, while some students do not consider studying at college to be self-evident yet, on the contrary, to be a precious farmhouse and are aware of the sense and importance of the study. Differences in research results can, of course, be influenced by the different student requirements of teachers.

Previous research has shown that effectively establishing time management and reducing the occurrence of procrastination contributes to a better feeling of work completed, increasing the performance of an individual, improving mood, and reducing adverse stress situations. At the same time, it is advisable to take steps to eliminate procrastination and the establishment of time management while studying at school, thus avoiding the occurrence of this unfavorable behavior at work, and by using right time management will a future employee be able to accomplish better performance.

\section{Acknowledgement}

This work was supported by research grant VEGA No. 1/0470/18 "Economic activity of tourism in the European area", and GAPU 43/2019 "Cultural differences and their impact on tourism" and GaPU 40/2019 "Health tourism in V4 countries" and GaPU 34/2018 "Current situation and identification of problem areas of administrative burden of EU projects in Slovakia".

Freund, J. E., Williams, F. J., Perles, B. M. (1988) "Elementary business statistics: a the modern approach", Prentice Hall, Englewood Cliffs, NJ, USA.

Gallo, P., Mihalčová, B., Timková, V., Tomčíková, L. (2018) "Importance of Financial and Non-financial Indicators in Companies with the Balanced Scorecard Concept", QUALITY - Access to success, 19(165), pp. 34-38.

Hen, M., Goroshit, M. (2018) "The effects of decisional and academic procrastination on students' feelings toward academic procrastination", Current Psychology.

https://doi.org/10.1007/s12144-017-9777-3

Košíková, M., Koval’ová, J., Timková, V. (2017) "Analýza rozdielov v time managemente a identifikácia faktorov ovplyvňujúcich výskyt prokrastinácie u študentov" (Analysis of the difference in time management and identification of factors affecting the occurrence of student's procrastination), In: Zvládanie náročných situácií a stresu v manažmente, Bookman, Prešov, Slovakia, pp. 37-41. (in Slovak) 
Lahmers, A. G., Zulauf, C. R. (2000) "Factors Associated with Academic Time Use and Academic Performance of College Students: A Recursive Approach", Journal of College Student Development, 41(5), pp. 544-556

Martínez-Murcia, F. J., Górriz, J. M., Ramírez, J., Puntonet, C. G., Salas-González, D. (2012) "Computer Aided Diagnosis Toll for Alzheimer's Disease based on Mann-Whitney-Wilcoxon U-Test", Expert Systems with Applications, 39(10), pp. 9676-9685. https://doi.org/10.1016/j.eswa.2012.02.153

Nábělková, E., Ledejová, N. (2012) "Procrastination in Context with Chosen Aspect of Self-regulation", In: Conference: 30. Psychologické dny: Prostor v nás a mezi námi - respekt, vzájemnost, sdílení, Olomouc, Czech Republic, pp. 309-318.

Özer, B. U., Demir, A., Ferrari, J. R. (2009) "Exploring Academic Procrastination Among Turkish Students: Possible Gender Differences in Prevalence and Reasons", The Journal of Social Psychology, 149(2), pp. 241-257. https://doi.org/10.3200/SOCP.149.2.241-257

Pychyl, T. A. (2009) "Active Procrastination: Thoughts on Oxymorons", Psychology Today, [online] Available at: http://www.psychologytoday.com/blog/dont-delay/200907/active-procrastination-thoughts-oxymorons [Accessed: 07 July 2019]

Rajnoha, R., Štefko, R., Merková, M., Dobrovič, J. (2016) "Business intelligence as a key information and knowledge tool for strategic business performance masanagement", Economics and Management, 19(1), pp. 183-203. https://doi.org/10.15240/tul/001/2016-1-013

Rimarčík, M. (2007) "Štatistika pre prax" (Statistics for practice), Marián Rimarčík, Košice, Slovakia. (in Slovak)
Schraw, G., Wadkins, T., Olafson, L. (2007) "Doing the things we do: A grounded theory of academic procrastination", Journal of Educational Psychology, 99(1), pp. 12-25. https://doi.org/10.1037/0022-0663.99.1.12

Schouwenburg, H. C., Lay, C. H., Pychyl, T. A., Ferrari, J. R. (2004) "Counseling the Procrastinator in Academic Settings", In: Internationalisation Within Higher Educational In An Expending Europe. New Developments In Psychological Counseling, FEDORA PSYCHE Conference in Groningen, Groningen, The Netherlands, pp. 67-80.

Singh, D., Jain, S. C. (2013) "Working process of time management in SAP HR module", International Journal of Management Research and Reviews, 3(1), pp. 2284-2297.

Stanková, N. (2016) "Význam a podstata time managementu u študentov PBF" (Importance and essence of time management of PBF students), Prešovská univerzita v Prešove, Pravoslávna bohoslovecká fakulta, Prešov, Slovakia. (in Slovak)

Steel, P. (2007) "The nature of procrastination: A meta-analytic and theoretical review of quintessential self-regulatory failure", Psychological Bulletin, 133(1), pp. 65-94. https://doi.org/10.1037/0033-2909.133.1.65

Sojka, L., Harausová, H., Malák, M., Kamenec, P., Krúpová, I. (2010) "Manažment II" (Management II), Prešovská univerzita, Fakulta manažmentu, Prešov, Slovakia. (in Slovak)

Tsai, H. C., Liu, S. H. (2015) "Relationships between time-management skills, Facebook interpersonal skills and academic achievement among junior high school students", Social Psychology of Education: An International Journal, 18(3), pp. 503-516. https://doi.org/10.1007/s11218-015-9297-7 